A bizonyítékokon alapuló orvoslás gondolatkörének a megjelenése az orvosi- és egészségtudományi képzésben

KÉRDŐÍV ORVOSTANHALLGATÓK SZÁMÁRA

\title{
Háttér információ
}

1. Hallgató neme
a. férfi
b. nő

2. Hányadik évfolyamon hallgatója vagy?
a. első
b. második
c. harmadik
d. negyedik
e. ötödik
f. hatodik

3. Dolgoztál már korábban az egészségügyben (legalább 1 évet)?
a. igen
b. nem

4. Tanulmányaid mellett részt veszel kutatócsoport munkájában (pl. TDK munka keretében)?
a. igen
b. nem

5. A közeli hozzátartozóid között (szülők, testvérek, házastárs) van olyan, aki az egészségügyben dolgozik?
a. igen
b. nem

6. Ha igen, hatással volt ez a pályaválasztásodra?
a. igen
b. nem

7. Milyen gyakran olvasol szakmai folyóiratokat?
a. naponta
b. hetente
c. havonta vagy ritkábban
d. soha 
8. Rendelkezel saját számítógéppel?
a. igen
b. nem

9. Van internet hozzáférésed?
a. igen
b. nem

10. Van ingyenes internet hozzáférésed?
a. igen
b. nem

11. A következő kereső felületek közül melyiket használtad már orvosi/ egészségügyi információ szerzésére?
a. Google
b. Google scholar
c. Wikipedia
d. Pubmed/Medline
e. Medscape
f. Cochrane Library

12. Mit tekintesz az egészségügyi információszerzés fő forrásának?
a. nyomtatott szakkönyvek
b. nyomtatott folyóiratok
c. elektronikus szakkönyvek
d. elektronikus folyóiratok
e. elektonikus média
f. szakmai irányelvek
g. szórólapok
h. oktatási jegyzetek
i. egészségügyi szakemberek véleményének megismerése

13. Vettél már részt szakmai képzésen (kurzus, tanfolyam), ahol a bizonyítékokon alapuló orvoslással (BAO, EBM) kapcsolatos ismereteket szereztél?
a. igen
b. nem

14. Ha igen, hasznosnak tartottad a képzést a további tanulmányaid illetve a későbbi munkád szempontjából?
a. igen
b. nem

15. Ha nem, hasznosnak tartanál egy ilyen képzést a további tanulmányaid illetve a későbbi munkád szempontjából? 

a. igen
b. nem

16. Ha igen, melyik évfolyamon lenne szerinted hasznos az EBM oktatása?
a. az 1.-2. évfolyamon
b. a 3.-4. évfolyamon
c. az 5.-6. évfolyamon

17. Szerepet játszik-e az adott egészségügyi információ nyelve abban, hogy elolvasod-e?
a. Igen, csak magyarul szeretek olvasni
b. Igen, csak angolul szeretek olvasni
c. Nem, az angol és magyar nyelvű forrásokat egyaránt elolvasom
d. Nem, sőt, olvastam már olyan forrást is, ami egyéb (nem angol vagy magyar) nyelven íródott


EBM tudás felmérés:

Milyennek ítéled a készségeidet a következő területeken?

\begin{tabular}{|l|c|c|c|c|c|}
\hline & Gyenge & $\begin{array}{c}\text { Van } \\
\text { valamennyi } \\
\text { tapasztalatom }\end{array}$ & Átlagos & $\begin{array}{c}\text { Átlagosnál } \\
\text { jobb }\end{array}$ & $\begin{array}{c}\text { Haladó } \\
\text { szintú }\end{array}$ \\
\cline { 2 - 6 } & $\mathbf{( 1 )}$ & $\mathbf{( 2 )}$ & $\mathbf{( 3 )}$ & $\mathbf{( 4 )}$ & (5) \\
\hline $\begin{array}{l}\text { Szakmai irodalom } \\
\text { keresése }\end{array}$ & & & & & \\
\hline $\begin{array}{l}\text { Keresés online } \\
\text { adatbázisokban }\end{array}$ & & & & & \\
\hline $\begin{array}{l}\text { Klinikai kutatásokat leíró } \\
\text { közlemények kritikus } \\
\text { értékelésé }\end{array}$ & & & & & \\
\hline $\begin{array}{l}\text { Olyan fontos klinikai } \\
\text { területek azonosítása, } \\
\text { ahol még nem áll } \\
\text { rendelkezésre elég } \\
\text { szakirodalom }\end{array}$ & & & & & \\
\hline $\begin{array}{l}\text { A rendelkezésre álló } \\
\text { szakirodalom kritikus } \\
\text { megítélése }\end{array}$ & & & & & \\
\hline $\begin{array}{l}\text { Betegek szempontjából } \\
\text { fontos kérdések } \\
\text { azonosítása }\end{array}$ & & & & & \\
\hline
\end{tabular}


Önbevalláson alapuló fogalomismeret: Mennyire ismered az alábbi fogalmakat?

\begin{tabular}{|c|c|c|c|c|c|}
\hline & $\begin{array}{c}\text { Értem a } \\
\text { jelentését, } \\
\text { és } \\
\text { másoknak } \\
\text { is el } \\
\text { tudnám } \\
\text { magyarázni }\end{array}$ & $\begin{array}{l}\text { Többé- } \\
\text { kevésbé } \\
\text { értem a } \\
\text { jelentését }\end{array}$ & $\begin{array}{c}\text { Nem } \\
\text { ismerem a } \\
\text { jelentését, } \\
\text { de } \\
\text { szeretném } \\
\text { megismerni }\end{array}$ & $\begin{array}{c}\text { Nem } \\
\text { ismerem a } \\
\text { jelentését, } \\
\text { de } \\
\text { szerintem } \\
\text { nem is } \\
\text { hasznos } \\
\text { számomra }\end{array}$ & $\begin{array}{c}\text { Nincs } \\
\text { véleményem } \\
\text { ezzel } \\
\text { kapcsolatosan }\end{array}$ \\
\hline $\begin{array}{l}\text { bizonyítékokon } \\
\text { alapuló orvoslás } \\
\text { (evidence-based } \\
\text { medicine) }\end{array}$ & & & & & \\
\hline $\begin{array}{l}\text { eredeti kezelési } \\
\text { szándék szerinti } \\
\text { elemzés (intention- } \\
\text { to-treat analysis) }\end{array}$ & & & & & \\
\hline $\begin{array}{l}\text { esetszám (sample } \\
\text { size) }\end{array}$ & & & & & \\
\hline $\begin{array}{l}\text { esettanulmány (case } \\
\text { study) }\end{array}$ & & & & & \\
\hline $\begin{array}{l}\text { kohorsz vizsgálat } \\
\text { (cohort study) }\end{array}$ & & & & & \\
\hline $\begin{array}{l}\text { konfidencia } \\
\text { intervallum }\end{array}$ & & & & & \\
\hline $\begin{array}{l}\text { kontrollált klinikai } \\
\text { vizsgálat }\end{array}$ & & & & & \\
\hline $\begin{array}{l}\text { lemorzsolódás (lost } \\
\text { to follow-up) }\end{array}$ & & & & & \\
\hline meta-analízis & & & & & \\
\hline $\begin{array}{l}\text { NNT (number needec } \\
\text { to treat) }\end{array}$ & & & & & \\
\hline $\begin{array}{l}\text { randomizálás } \\
\text { (randomization) }\end{array}$ & & & & & \\
\hline $\begin{array}{l}\text { szakmai irányelv } \\
\text { (guideline) }\end{array}$ & & & & & \\
\hline $\begin{array}{l}\text { szisztematikus } \\
\text { irodalmi áttekintés } \\
\text { (systematic review) }\end{array}$ & & & & & \\
\hline
\end{tabular}


Attitűd felmérés: Mennyire értesz egyet a következő állításokkal?

\begin{tabular}{|c|c|c|c|c|c|}
\hline & $\begin{array}{l}\text { Egyáltalán } \\
\text { nem értek } \\
\text { vele egyet }\end{array}$ & $\begin{array}{l}\text { Nem } \\
\text { értek } \\
\text { egyet }\end{array}$ & Semleges & $\begin{array}{l}\text { Egyet } \\
\text { értek }\end{array}$ & $\begin{array}{l}\text { Kifejezetten } \\
\text { egyet értek }\end{array}$ \\
\hline $\begin{array}{l}\text { A bizonyítékokon alapuló } \\
\text { orvoslás (BAO) fontos a } \\
\text { gyakorló orvos munkája } \\
\text { szempontjából }\end{array}$ & & & & & \\
\hline $\begin{array}{l}\text { Szeretném, hogy a } \\
\text { tanulmányaim során azon } \\
\text { képességeim fejlődjenek, } \\
\text { mely a bizonyítékokon } \\
\text { alapuló orvoslás (BAO) } \\
\text { gyakorlati orvosi munka } \\
\text { során történő } \\
\text { alkalmazásához szükséges }\end{array}$ & & & & & \\
\hline $\begin{array}{l}\text { A bizonyítékokon alapuló } \\
\text { orvoslás fontos a betegek } \\
\text { optimális ellátásához }\end{array}$ & & & & & \\
\hline $\begin{array}{l}\text { A bizonyítékokon alapuló } \\
\text { orvoslás elősegíti a } \\
\text { betegek ellátásával } \\
\text { kapcsolatos } \\
\text { döntéshozatalt }\end{array}$ & & & & & \\
\hline $\begin{array}{l}\text { A bizonyítékokon alapuló } \\
\text { orvoslás figyelembe veszi } \\
\text { a gyakorló orvosok egyéni } \\
\text { tapasztalatait }\end{array}$ & & & & & \\
\hline $\begin{array}{l}\text { A bizonyítékokon alapuló } \\
\text { orvoslás figyelembe veszi } \\
\text { a betegek kezeléssel } \\
\text { kapcsolatos véleményét, } \\
\text { preferenciáit }\end{array}$ & & & & & \\
\hline $\begin{array}{l}\text { Fontos, hogy a kutatási } \\
\text { eredmények beépüljenek } \\
\text { az orvosi gyakorlatba }\end{array}$ & & & & & \\
\hline $\begin{array}{l}\text { Minden klinikai vizsgálat } \\
\text { azonos értékű }\end{array}$ & & & & & \\
\hline $\begin{array}{l}\text { A bizonyítékokon alapuló } \\
\text { orvoslás gyakorlati } \\
\text { alkalmazása } \\
\text { megvalósíthatatlan terhet } \\
\text { ró az egészségügyben } \\
\text { dolgozókra }\end{array}$ & & & & & \\
\hline $\begin{array}{l}\text { A betegek ellátásával } \\
\text { kapcsolatban felmerülő }\end{array}$ & & & & & \\
\hline
\end{tabular}




\begin{tabular}{|l|l|l|l|l|l|}
\hline $\begin{array}{l}\text { kérdéseimre a } \\
\text { legmegfelelőbb választ } \\
\text { szakkönyvekból kaphatom }\end{array}$ & & & & & \\
\hline Leendó egészségügyi & & & & & \\
dolgozóként fontosnak & & & & & \\
tartom az egész életen át & & & & & \\
tartó tanulást & & & & \\
\hline
\end{tabular}

